\title{
Relacijske rodne strategije u podjeli kućanskih poslova
}

DOI: $10.5613 /$ rzs.50.3.1

UDK 316.36:316.4.063.22

$64: 316.36$

Izvorni znanstveni rad

Primljeno: 5. 6. 2020.

\author{
Augustin DERADO (iD https://orcid.org/0000-0003-0114-6792 \\ Institut društvenih znanosti Ivo Pilar, Hrvatska \\ augustin.derado@pilar.hr
}
Mirko PETRIĆ (DD https://orcid.org/0000-0002-0604-5352
Institut društvenih znanosti Ivo Pilar i Sveučilište u Zadru, Hrvatska
mirko.petric@pilar.hr

\author{
Inga TOMIĆ-KOLUDROVIĆ (D) https://orcid.org/0000-0003-1465-0365 \\ Institut društvenih znanosti Ivo Pilar, Hrvatska \\ inga.tomic-koludrovic@pilar.hr
}

\section{SAŽETAK}

U članku se iznose rezultati kvalitativnog istraživanja rodne podjele kućanskih poslova u Hrvatskoj, u širem okviru ukupnih radnih praksi kućanstava (tj. ukupnoga plaćenog i neplaćenog rada koji pridonosi ostvarivanju njihovih ciljeva). Podatci su prikupljeni kroz 92 polustrukturirana intervjua (34 s muškarcima, 43 sa ženama i 15 partnerskih), provedena u svim hrvatskim regijama, uz visok stupanj varijacije po sociodemografskim obilježjima. Primijenjena je relacijska rodna analiza, čiji je teorijski okvir počivao ponajprije na Bourdieuovu prakseološkom pristupu konceptu strategije, kao i na Pahlovoj konceptualizaciji ukupnog rada kućanstva, te analizi rodne dimenzije strategija kod Hochschild. Procesi kategorizacije uključivali su tri razine kodiranja (referentno, otvoreno i selektivno), a procesi povezivanja izradu analitičkih profila i tablica. Identificirane individualne rodne strategije povezane s obavljanjem kućanskih poslova jesu: strategije neupitnosti, otpora promjeni, suradnje, te proaktivne egalitarnosti (kod muškaraca) i strategije neupitnosti, pritiska, pristajanja, te proaktivne egalitarnosti (kod žena). Dovođenjem u odnos navedenih muških i ženskih individualnih strategija, uz

Zahvaljujemo suradnicama na projektu HRZZ-IP-2016-06-6010 (GENMOD) dr. sc. Lynette ŠikićMićanović i dr. sc. Rebeki Anić na doprinosima u svim fazama pripreme i provedbe kvalitativnog istraživanja na kojemu se temelji ovaj članak, te dr. sc. Sari Ursić na doprinosu u kodiranju. Zahvalni smo urednici časopisa Revija za sociologiju na komentarima koji su značajno pomogli unaprijediti tekst. 
primjenu kriterija rodne ravnoteže, dobivena je sljedeća tipologija strategija kućanstava u Hrvatskoj s obzirom na podjelu kućanskih poslova: neupitno tradicionalna, pretežno tradicionalna, početno egalitarna i proaktivno egalitarna. $U$ dijelu muških i ženskih individualnih strategija pojavljuje se i komponenta opravdavanja u podjeli kućanskih poslova. Teorijski je doprinos analize primjena Bourdieuova prakseološkog pristupa strategijama u relacijskom istraživanju roda.

Ključne riječi: podjela kućanskih poslova, relacijska analiza roda, kvalitativno istraživanje, Bourdieu, rodne strategije

\section{UVOD}

Otkad su objavljene pionirske studije o "sociologiji kućanskih poslova" (Oakley, 1974a) i "kućanici" (Oakley, 1974b), u zapadnoeuropskim je zemljama provedeno mnoštvo istraživanja na osnovu kojih se danas može empirijski utemeljeno govoriti o sličnostima i razlikama u asimetriji podjele rada u kućanstvu između žena i muškaraca u različitim nacionalnim kontekstima (vidjeti npr. Crompton, Lewis i Lyonette, 2007). U Hrvatskoj, pak, unatoč stalnom međunarodnom rastu znanstvenog interesa za proučavanje neplaćenog rada u kućanstvu, od sredine sedamdesetih do sredine devedesetih godina 20. stoljeća, nije objavljen nijedan rad o podjeli poslova između bračnih partnera (Topolčić, 2001: 768). Ta je tema svoju empirijsku dimenziju dobila tek u postsocijalističkom razdoblju, i to ponajprije istraživanjima koja se mogu svrstati u područje "kvantificirane nejednakosti" (Topolčić, 2001: 772). Od sredine devedesetih tako i u Hrvatskoj konačno postoje empirijski podatci koji se odnose na to tko u kućanstvu (žene ili muškarci) obavlja pojedine poslove, ili pak o predodžbama o tome koje bi poslove trebale obavljati žene a koje muškarci (Vučinić-Palašek, 1995; Leinert-Novosel,1999; Tomić-Koludrović i Kunac, 2000; Topolčić, 2000, 2003; Čulig, Kufrin i Landripet, 2007; Bartolac i Kamenov, 2013; Tomić-Koludrović, 2015; Klasnić, 2017; Tomić-Koludrović i dr., 2018). Objavljeni rezultati pojedinih kvalitativnih istraživanja također su relevantni za temu, no ta su istraživanja provedena samo sa specifičnim ženskim populacijama u ruralnom kontekstu (Barada, Čop i Kučera, 2011; Šikić-Mićanović, 2012). Konačno, no nipošto i manje važno, u postsocijalističkom su se razdoblju pojavili pregledi dotadašnjih eksplanatornih koncepata o podjeli rada u kućanstvu (Šikić-Mićanović, 2001; Topolčić, 2001, 2003) ili su se, pak, autor/ice više ili manje opsežno i kompleksno pozivali/e na te koncepte pri interpretaciji rezultata gore spomenutih istraživanja.

Međutim, unatoč tomu što su u postsocijalističkom razdoblju napokon stvorene empirijske i teorijske osnove za daljnje proučavanje teme podjele rada u kućanstvu, u Hrvatskoj su dosad posve izostala kvalitativna istraživanja koja bi tu podjelu 
obradila u perspektivi (rodnih) strategija, uz uzimanje u obzir ukupnih radnih praksi kućanstva. To na prvi pogled može djelovati iznenađujuće, jer - kao što je poznato - ekonomske i druge krize u prvi plan dovode upotrebu resursa u kućanstvima i njihove strategije preživljavanja, u kojima su žene u hrvatskom društvu (osobito u ratnom razdoblju na početku tranzicije) odigrale važnu ulogu (Tomić-Koludrović i Kunac, 2000). Osim očitog izostanka istraživačke tradicije u području, ${ }^{1}$ mogući razlog takvom stanju jest to što je u dosad objavljenoj literaturi na teme povezane s podjelom rada u kućanstvu naglasak bio ponajprije na položaju žena u obitelji ili u partnerskom odnosu, a ne na kućanstvu kao široj jedinici analize. Također, dosad su posve izostala kvalitativna istraživanja teme koja bi uključivala intervjuiranje muškaraca.

Kako bilo, činjenica jest da su dosad objavljena samo dva rada kojima su središnji predmet istraživanja strategije kućanstava u Hrvatskoj (Bagić i dr., 2017; Šikić-Mićanović, 2017) te još tri koja analiziraju podatke iz Hrvatske u regionalnom kontekstu (Cvetičanin i Lavrič, 2017; Efendić, Cvetičanin i Kumalić, 2017; Krstić i dr., 2017). Nijedan od tih radova ne sadržava građu ili zaključke o strategijama kućanskih poslova. $\mathrm{S}$ druge strane, niti jedan rad o podjeli kućanskih poslova u Hrvatskoj ne upotrebljava koncept strategije, koji u tom području rasprave nužno ima izraženu rodnu dimenziju.

Može se, dakle, zaključiti da u Hrvatskoj ne postoje dovoljne empirijske osnove za odgovor na istraživačka pitanja na koja će pokušati odgovoriti ovaj članak, a koja glase:

Kakve su individualne strategije muškaraca i žena u podjeli kućanskih poslova?

Kakva kućanstva postoje s obzirom na međuodnos individualnih strategija muškaraca i žena pri obavljanju kućanskih poslova?

Bagić i dr. (2017) kao prethodna istraživanja navode samo nekoliko radova koji su proučavali "neke aspekte" strategija kućanstava u Hrvatskoj (Karajić, 2002; Puljiz i dr., 2008; Dobrotić i Laklija, 2012; Rubić, 2013). Tomu valja pridodati još jedan, kasnije objavljeni rad (Rubić, 2017). 


\section{TEORIJSKI OKVIR}

Polazište analiza čiji se rezultati iznose u ovom članku može se sažeti na tvrdnju Morris (1989: 447-448) prema kojoj je kućanstvo logična jedinica analize, ${ }^{2}$ jer se tu muškarac i žena susreću u partnerskom odnosu, ${ }^{3}$ u svojim različitim ulogama. Ta je perspektiva ujedno sukladna pristupu "relacijske analize roda", na koju se također oslanja ovaj članak, a koju - pozivajući se na već klasične radove Connell (1987) i McKaya (1997) - Dworkin (2015: 171) možemo lapidarno definirati kao vrstu dolaska do društvenoznanstvene spoznaje koja uzima u obzir istodobno postojanje muškosti i ženskosti u istom referentnom okviru.

U ovom slučaju, referentni okvir predstavljaju strategije podjele kućanskih poslova. Naš pristup "strategijama" inspiriran je shvaćanjem tog koncepta u Bourdieuovoj $(1972,1980)$ prakseološkoj teoriji. Strategije, dakle, vidimo kao način ili logiku "nizanja praksi" koje su uvijek usmjerene postizanju nekog (društveno) objektivnog cilja, a nužno su i svjesne i nesvjesne (Bourdieu, 1972; Bourdieu i Wacquant, 1992: 25). ${ }^{4}$

Bourdieuovo shvaćanje strategija odabrano je stoga što odgovara našoj konceptualizaciji i analizi podjele kućanskih poslova kao dinamičnoga relacijskog rodnog procesa, zasnovanog na suradnji i sukobu između muškarca i žene u istom kućanstvu. Pri takvoj analizi, važno je i to što Bourdieuovo postavljanje strategija u središte svog viđenja relacijske sociologije omogućuje zahvaćanje kompleksnosti (kao i djelomične prikrivenosti) društvenih borbi, nejednakosti i načina dominacije. Konačno, Bourdieuova relacijska sociologija omogućuje konceptualizaciju obavljanja kućanskih poslova u okviru šireg skupa društvenih praksi i struktura, kojima se u istraživanju pristupalo kroz promatranje analiziranih praksi u okviru ukupnog rada kućanstva.

2 Kućanstvo definiramo kao zajednicu osoba koje žive zajedno "pod istim krovom" (u istom stanu ili kući), ili pak dijele resurse unatoč tome što je netko od članova/ica kućanstva povremeno ili privremeno odsutan/na (primjerice, na privremenom radu izvan mjesta stanovanja). U ovom članku, sljedeći Pahla (1984), promatramo ga, međutim, ponajprije kao jedinicu unutar koje se kombiniraju različite vrsta rada i resursa među više pojedinaca/ki, pri čemu ne impliciramo konsenzualnost takvih aranžmana. $U$ iznošenju rezultata fokusiramo se na prakse i strategije odraslih partnera/ica pri čemu kućanstvo predstavlja okvir njihovih praksi.

3 Ta definicija očito ne uzima u obzir neheteronormativne partnerske odnose, koje ne obrađujemo u ovom tekstu, iako su uključeni u empirijsko istraživanje na temelju kojega je nastao.

4 Valja naglasiti da Bourdieu - za razliku od teoretičara racionalnog izbora - pod strategijom ne smatra "svrhovito i unaprijed planirano slijeđenje proračunatih ciljeva". Njegovo shvaćanje strategija podrazumijeva "aktivno razvijanje objektivno usmjerenih 'nizova djelovanja' koji se pokoravaju pravilnostima i oblikuju koherentne i društveno razumljive obrasce, iako ne slijede svjesna pravila i ne smjeraju unaprijed promišljenim ciljevima koje postavlja strateg" (Bourdieu i Wacquant, 1992: 25). 
S obzirom na to da analizirane prakse imaju izrazitu rodnu dimenziju, oslonili smo se i na pojam "rodne strategije", koji je uvela Arlie Hochschild (1989). U njezinu radu taj se pojam odnosi na djelovanja kroz koja "osoba pokušava riješiti probleme pred sobom s obzirom na kulturne predodžbe roda" (Hochschild, 2003 [1989]:15). Rad te sociologinje važan nam je i stoga što se njezino shvaćanje i empirijsko istraživanje rodnih strategija temeljilo upravo na analizi obavljanja kućanskih poslova te je uključivalo i muškarce i žene.

Kao što je već spomenuto, individualne rodne strategije podjele kućanskih poslova u analizi promatramo u širem okviru ukupnog rada kućanstva, odnosno skupa "praksi koje članovi kućanstva kolektivno ili individualno usvajaju da bi obavili posao" koji smatraju da treba biti obavljen (Pahl, 1985: 251). Uz kućanske poslove (u kući, oko kuće te brigu za djecu i starije), u prakse koje pridonose ciljevima kućanstva ubrajaju se: formalni (plaćeni) rad (uključujući i samozaposlene), neformalni plaćeni rad u različitim oblicima, neformalni neplaćeni rad (razmjena usluga i proizvoda), proizvodnja (ponajprije hrane) za vlastite potrebe te usluge za vlastite potrebe (različiti popravci, građevinski i majstorski radovi koji bi inače trebali biti plaćeni) (usp.npr. Babović i Cvejić, 2002; Cvetičanin i Lavrič, 2017).

Budući da se strategije kućanstva u obavljanju kućanskih poslova mogu opisati kao susret individualnih (rodno diferenciranih) strategija, pri procjeni njihova karaktera oslanjali smo se na kriterij "rodne ravnoteže". U javnim politikama i diskursu "korporacijske društvene odgovornosti" taj se kriterij opisuje kao "stanje u kojem i muškarci i žene imaju jednake mogućnosti i pristup svim institucijama u društvu" (Omotosho, 2013: 43). Sadržaj i intencije te i sličnih definicija ${ }^{5}$ ovdje su primijenjeni pri analizi praksi i strategija koje se obavljaju u kućanstvu te izradi tipologije strategija kućanstava koja je nastala na temelju tih analiza.

5 Primjerice, strategija rodne ravnopravnosti nizozemske vlade usmjerena je prema promicanju "jednakih prava, mogućnosti i odgovornosti za muškarce i žene”, a jedan od njezinih glavnih ciljeva jest omogućiti da muškarci i žene pravednije dijele odgovornost za poslove izvan kuće i u kućanstvu (Government of the Netherlands, 2020). 


\section{METODOLOGIJA}

Istraživanje na kojem se temelje rezultati analize prezentirane u članku dio je šireg projekta o rodnim identitetima i odnosima muškaraca i žena u Hrvatskoj. ${ }^{6}$ Istraživanje je etički vrednovala i odobrila znanstvena institucija pri kojoj se projekt provodi.

\subsection{Uzorkovanje}

Podatci su prikupljeni iz 92 polustrukturirana intervjua (34 individualna intervjua s muškarcima, 43 individualna intervjua sa ženama te 15 partnerskih intervjua) ${ }^{7}$, provedena sa sugovornicima/ama različitih sociodemografskih obilježja, u svim hrvatskim regijama. Uzorkovanje se rukovodilo načelom postizanja heterogenosti koja omogućuje usporedbe (Maxwell, 2013: 89-90). Izbor sugovornika/ca rukovodio se kombinacijom formalne i teorijske logike (Flick, 2007: 26) te je stoga bio ujedno unaprijed određen i izranjajući (Emmel, 2013: 85). Formalna logika i unaprijedno određenje pritom se odnose na odluku da se u različitim hrvatskim regijama ${ }^{8}$ intervjuira približno podjednak broj sugovornika/ca, uz varijacije po značajkama za koje je procijenjeno da su važne (tip naselja, obrazovanje, ekonomski status, zaposlenost i dob). Dio sugovornika/ca identificiran je na temelju anketnog upitnika koji su ispunjavali/e u prethodnoj fazi šireg projekta unutar kojega je provedeno istraživanje. Ostali su pronađeni korištenjem osobnih kontakata istraživača/ica i preko pomno odabranih posrednika/ca (Kristensen i Ravn, 2015). Teorijska logika primijenjena je osobito u kasnijim dijelovima sekvencijalnog uzorkovanja. Naime, terensko je istraživanje u svakom pojedinom slučaju uključivalo "razmišljanje zašto je [...] važan i kakve bi još slučajeve trebalo intervjuirati" (Miles i Huberman, 1984: 36), odnosno potragu za "konceptualno značajnim slučajevima" koji nedostaju (Weiss, 1994: 31-32) i koji su birani na temelju teorijskog predznanja i prethodnoga istraživačkog iskustva.

6 Riječ je o projektu "Relacijski rodni identiteti u Hrvatskoj: modernizacijske i razvojne perspektive" (GENMOD) (HRZZ-IP-2016-06-6010).

7 Osobe koje su sudjelovale u partnerskim intervjuima nisu zasebno individualno intervjuirane. Tijekom provođenja partnerskih intervjua, sugovornicima i sugovornicama su pružene prilike za izražavanje razlika u mišljenjima i neslaganja s partnerovim/ičinim tvrdnjama i objašnjenjima, pri čemu je posebna pozornost pridavana tematici podjele kućanskih poslova. Sukladno onomu što se navodi u literaturi na temu (Nyman, Reinikainen i Eriksson, 2018; Bjørnholt i Farstad, 2012), pokazalo se da partnerski intervjui omogućuju spoznaje koje se ne mogu dobiti iz individualnih intervjua. U ovom slučaju, partnerski intervjui omogućili su praćenje "na licu mjesta" kako se sudionici/e konstituiraju kao par kroz verbalne i neverbalne interakcije (međusobne i i intervjuistom/ icom).

8 Regije kojima je u istraživanju pokriven teritorij Hrvatske bile su: Sjeverna Hrvatska; Slavonija; Banovina, Kordun i Lika; Hrvatsko primorje i Istra; Dalmacija te regija Zagreb. 


\subsection{Provedba intervjua}

Intervjui su provođeni po protokolima koji su obuhvaćali širi skup tema povezanih s rodnim identitetima i partnerskim odnosima, pri čemu su teme važne za analizu prezentiranu u ovom članku bile među temeljnima. Intervjue su provodile dvije istraživačice i jedan istraživač ${ }^{9}$, a trajali su između 48 minuta i 200 minuta (većinom dulje od 80 minuta). Pri provođenju intervjua prikupljane su i mikroetnografske bilješke ${ }^{10}$, koje su kasnije upotrijebljene pri interpretaciji podataka i konstrukciji profila intervjuiranih i kućanstava u kojima žive. Iz anketnih upitnika koje su ispunjavali sugovornici/e dobiveni su sociodemografski i drugi podatci korišteni pri izradi profila i u analizama koje su uslijedile. Svi su intervjui u cijelosti transkribirani i anonimizirani.

\subsection{Kodiranje i proces povezivanja podataka}

Kvalitativna analiza provedena je izmjenjivanjem analitičkih procesa kategorizacije i procesa povezivanja (Maxwell i Chmiel, 2014). Procesi kategorizacije uključivali su tri razine kodiranja (referentno, otvoreno i selektivno), a procesi povezivanja izradu analitičkih profila i tablica. Prva razina kodiranja provedena je s ciljem oblikovanja temeljnih kategorija organizacije materijala te njegova razvrstavanja i pripreme za

$9 \quad$ Kad je riječ o pozicioniranju interjvuista/ica u odnosu na intervjuirane, valja napomenuti da se procesu intervjuiranja pristupalo kao susretu ukupnosti različitih dispozicija. To znači da se rodu pristupalo kao važnom elementu u susretu različitih habitusa intervjuista/ica i intervjuiranih, ali da nije zanemarivana važnost dobnih, obrazovnih i statusnih razlika među njima. Moguće poteškoće opisane u metodološkim razmatranja intervjuiranja u istraživanju roda (Reinharz i Chase, 2003; Schwalbe i Wolkomir, 2003), minimizirane su time što su intervjuistice svojim simboličkim kapitalom i vještinama intervjuiranja najvećim dijelom uspijevale neutralizirati pokušaje zauzimanja pozicije hegemonijske muškosti u sugovornika ili taktike zatvaranja narativa u situacijama kad je takva muškost bila ugrožena. Intervjuist je, pak, s obzirom na to da je muškarac mlađe dobi, minimizirao ugrožavanje hegemonijske muškosti sugovornika svojom pojavnošću "neopasnog" muškarca i taktikom neasertivnosti. Ista taktika, kao i naglašeno "slušačka" i "kooperativna" pozicija tijekom vođenja intervjua, minimizirali su moguće nepovjerenje žena prema (muškom) rodu intervjuista. Pokazalo se da su oba pristupa (onaj intervjuistica i onaj intervjuista) omogućavala dijaloge s različitim muškostima i ženskostima, a razlike u susretu različitih dispozicija i rodnih identiteta rezultirale su dodatnim spoznajama, a ne poteškoćama ("šumom"), u analizi (Schwalbe i Wolkomir, 2003, 58-59).

10 Mikroetnografske bilješke obuhvatile su: fizički izgled i govor tijela sugovornika/ca, odjeću koju su tijekom intervjua nosili/e, mimiku i govorni jezik, skup obilježja prostora u kojemu žive (a koji je osim regionalne i mikrolokacije uključivao i tip prostora te njegovu veličinu, kao i vanjsko i unutarnje uređenje, vrstu pokućstva te podatke o ukrasima, umjetničkim djelima i religijskim predmetima). Bilježene su i reakcije na pitanja u intervjuima (poput promjene govora tijela i tona glasa), kao i eventualni nesklad između onoga što sugovornici/e govore i kako se ponašaju. Posebna je pozornost interakcijskim elementima pridavana kod partnerskih intervjua. 
daljnju analizu primjenom referentnog kodiranja ${ }^{11}$ (Kelle, 2007a: 454). Konstrukciju referentnih kodova provele su dvije istraživačice: jedna deduktivnim kodiranjem na temelju konceptualnog okvira, a druga induktivnim deskriptivnim kodiranjem, koje je bilo vođeno podatcima prikupljenim na terenu (Miles i Huberman, 1994: 57-58). Na temelju tih kodova, treći je istraživač izradio verziju kodova ovjerenu u grupnim podatkovnim sesijama, u kojima su sudjelovali sve/i članice/ovi tima (što uključuje obje intervjuistice i intervjuista). Nakon kategorizacije referentnim kodiranjem, prva tehnika povezivanja dobivenog materijala bila je izrada analitičkih profila dvadeset teorijski saturiranih slučajeva različitih tipova partnerskih odnosa, s osobitim naglaskom na podjelu kućanskih poslova ${ }^{12}$. Cilj takvog povezivanja bio je pospješiti razumijevanje logike različitih slučajeva (Bazeley, 2013: 189) "prepoznavanjem supstancijalnih veza" među analiziranim pojavama, odnosno zapažanjem interakcija između - u međuvremenu kodiranjem razlomljenih - kategorija (Dey, 1993: 161).

U sljedećoj fazi rada, kao izvor teorijske osjetljivosti daljnjih analiza (Kelle, 2007b), uvedena je analitička perspektiva usredištena na rodnu dimenziju individualnih strategija obavljanja kućanskih poslova. Kategorizirani relevantni dijelovi transkripata - promatrani u odnosu s transkriptima u cjelini te s izrađenim analitičkim profilima - dalje su proučavani načinom inspiriranim "otvorenim kodiranjem" utemeljene teorije Glasera i Straussa (1967). Drugim riječima, nakon obavljenoga temeljnog senzibiliziranja na perspektivu strategija, analizirani materijal gledao se "novim očima" i čitao ciklički, uz rafiniranje analitičke perspektive spoznajama stečenim svakim novim čitanjem.

U posljednjoj fazi analitičkog rada obavljeno je selektivno kodiranje osobito teorijski zasićenih dijelova transkripata, pri čemu je koncept "strategije" od perspektive namijenjene teorijskom senzibiliziranju prerastao u središnju kategoriju analize. Pritom su se kristalizirale značajke i dimenzije koje su omogućile konstrukciju tipologije rodno diferenciranih individualnih strategija povezanih s podjelom kućanskih poslova.

Nakon toga je, kroz izradu analitičkih tablica usporedbe slučajeva (Gibbs, 2007: 80-84), uslijedio proces povezivanja dobivenih individualnih strategija. Uzimanjem u obzir svih relevantnih kategorija za analizu pojedinog slučaja ${ }^{13}$ i zatim uspored-

11 Referentno kodiranje, kao i kasnije otvoreno i selektivno kodiranje, obavljeno je u računalnom programu QDA Miner 5, a provođeno je uz vođenje dnevnika kodiranja, pisanje analitičkih bilješki i pridržavanje uobičajenih procedura osiguravanja pouzdanosti.

12 U profilima je uz kućanske poslove obuhvaćen i sav drugi rad koji članovi kućanstva obavljaju.

13 Uz dosad navedene kategorije (koje se odnose na obavljanje kućanskih poslova i drugih vrsta rada), uzimani su u obzir podatci o rodnoj socijalizaciji intervjuiranih, materijalnim strukturnim čimbenicima važnim za pojedini slučaj te elementima rodnih ideologija nazočnim u narativima. 
bama između slučajeva - uz integraciju teorije i primjenu kriterija rodne ravnoteže - izrađena je tipologija strategija kućanstava u obavljanju kućanskih poslova.

\section{REZULTATI}

Zbog opsežnosti analizirane građe i ograničenog prostora za njezin prikaz, rezultati istraživanja u nastavku se teksta donose sintetski, uz kratko objašnjenje kriterija razvrstavanja i (skraćene) ilustrativne izvatke iz transkripata intervjua. Najprije se prezentiraju rezultati istraživanja povezani s individualnim rodnim strategijama pri obavljanju kućanskih poslova, a potom komponenta opravdavanja, koja se pojavljuje u više njih. Na koncu slijedi pregled rezultata dobivenih tipova strategija kućanstava u podjeli kućanskih poslova, kategoriziranih na temelju kriterija rodne ravnoteže. Navedenu strategiju kućanstva pritom čine kombinacije muških i ženskih individualnih strategija i njihov međuodnos, promatran u odnosu s ukupnim radom kućanstva.

\subsection{Individualne strategije povezane s obavljanjem kućanskih poslova}

Pri analizi rezultata istraživanja koji se odnose na narative intervjuiranih o partnerskoj podjeli rada povezanoj s kućanskim poslovima, pokazalo se da su individualne strategije u tom pogledu jasno rodno diferencirane. Logičan način prikaza je stoga njihovo grupiranje u muške i ženske individualne strategije. Nadalje, s obzirom na to da se usmjerenost pojedine strategije (i nizanje praksi koje ona podrazumijeva) najbolje vidi po njezinim ciljevima, u nastavku ih tako i prikazujemo.

\subsubsection{Muške strategije}

$U$ individualne muške strategije ubrajaju se strategije neupitnosti, otpora promjeni, suradnje, te proaktivne egalitarnosti.

Cilj muške strategije neupitnosti održavanje je neupitnosti tradicionalnoga rodnog poretka, ${ }^{14}$ a time i tradicionalne podjele kućanskih poslova. Kad je $u$ intervjuima neki element takvog rodnog poretka bio doveden u pitanje, u ovoj se

14 Tradicionalni rodni poredak počiva na rodnoj ideologiji koja "naglašava vrijednosti razlikovnih uloga žena i muškaraca. Primjerice, prema tradicionalnoj rodnoj ideologiji o obitelji, muškarci ispunjavaju svoje obiteljske uloge kroz instrumentalne, hraniteljske aktivnosti, a žene obavljaju svoje uloge kroz njegovateljske, kućanske i roditeljske aktivnosti. Za razliku od toga, egalitarne ideologije koje se tiču obitelji podržavaju i vrednuju jednake i dijeljene hraniteljske i njegovateljske obiteljske uloge." (Kroska, 2007: 1867). 
strategiji on branio kao "prirodan", a podjela poslova između muškaraca i žena smatrala se "normalnom" i "jasnom" ("ona normalno da radi ono što je... ono što kažu... žensku domenu").

Štoviše, rodna se podjela kućanskih poslova u diskursu sugovornika/ca ponekad činila toliko jasnom da se podrazumijevalo da ona ni ne zahtijeva eksplikaciju. Nekima je, pak, bilo teško uopće artikulirati mišljenje o njoj ("većinom... ona je... normalna stvar, po kući ona [supruga] napravi...”). Samo postavljanje pitanja te vrste shvaćalo se kao nesvakidašnje, potencijalno remetilačko i "nepotrebno" ("pa to ti žene uglavnom rade"). Primjerice, upitan o podjeli kućanskih i drugih poslova od vremena kad su on i partnerica zasnovali zajedničko kućanstvo, jedan je sugovornik odgovorio ovako:

Ante: To iz prijašnjeg razgovora... može se to zaključit... na koji sistem smo radili, kako podjela poslova. Bože moj, ona je kuvala kako i je normalno u kući... i to... (...) Bože moj, spremit ručak, zna se šta je ženski posa! Znači oprat to, spremit ručak i spremit dicu. (Ante, 44, selo)

Muškarci s ovakvom strategijom vide podjelu kućanskih poslova kao dio tradicije i povezuju je s vlastitom primarnom socijalizacijom:

Pave: Načistu smo bili od samog početka, da u te stvari se ja petljati neću! Dakle, ono što je moj otac prepustio dakle... ženskoj čeljadi, što bi se reklo, tako sam ja mojoj gospođi. (Pave, 70, selo)

Kroz intervjue je bilo jasno da muškarci sa strategijom neupitnosti smatraju da su žene sposobnije za kućanske poslove i brigu o djeci ("njima je to nekako lakše nego muškarcima"), pa i da je to dio njihove "prirode".

Karlo: Ne, to se nije promijenilo u zadnjih pet tisuća godina (smijeh) (...) mnogi griješe u toj stvari, oni pokušavaju bit ono što prirodno nisu... (Karlo, 64, mali grad)

Iz izjava muškaraca sa strategijom neupitnosti proizlazi da ne obavljaju nikakve kućanske poslove, osim onih koje smatraju jasno "muškim" (popravci, zanatski rad, te drugi poslovi vezani uz tehniku i fizičku snagu).

Cilj muške strategije otpora promjeni jest obrana tradicionalne podjele kućanskih poslova i time zadržavanje tradicionalnih rodnih uloga. Različitim načinima izvođenja te strategije muškarci nastoje povući i braniti granice o tome koji su poslovi "njihovi” i koje kućanske poslove mogu ponekad obaviti. 
Granice nastoje povući na poslovima koji su "najviše muški" (automobil, popravci, drva za ogrjev i sl.) uz (rijetko) povremeno sudjelovanje u kućanskim poslovima (usisavanje, kuhanje, pospremanje).

Goran: Znači, ja bi one vanjske radove, uglavnom, gospođa se bavi čišćenjem kuće... veš, mislim, naravno, svi ovi standardni, klasični kućanski poslovi. (...) Sad treba garažu očistit... sad je tu svađa. Ja tvrdim da je to unutar kuće, da se ja tim ne bavim. A ona naravno inzistira pošto je tu auto i drva, pa da ja radim taj nered (...) u našoj vezi je zanimljivo da ja obožavam kuhat. Meni je kuhanje stvarno jedan hobi... tako da, evo, gospođa se baš kuhinje previše ne hvata. Inače, punica mi je isto profesionalni kuhar, tako da preko tjedna smo u biti svaki dan kod nje na ručku. (Goran, 41, prigradsko naselje)

Načini izvođenja muške strategije otpora jesu: nezainteresiranost, namjerno razdvajanje od sfere kućanskih poslova te izostanak volje za učenje o tome kako obaviti kućanske poslove ("ja ne bi reko da bi znao baš uključiti veš mašinu”"15, "ne zna on oribat kupatilo, to nije nikad"). Slijede zatim loša kvaliteta i nemarno obavljanje kućanskih poslova ("uvijek [se] držao sredine, gurnut sauger ili metlu ispod kreveta - to ne") te pozivanje na drugačije percepcije standarda urednosti ("mi imamo različite, te nekakve percepcije urednosti”, "meni može bit... mogu živit u planinarskom domu bez problema").

Zabilježeno je i izbjegavanje kućanskih poslova odlaskom s mjesta njihova obavljanja (npr. iz kuhinje u dnevnu sobu, izlaskom u dvorište, odlaskom u radionicu ili garažu te odlaskom iz kućanstva). Takvi se potezi svode na zaključak da "netko mora", a jasno je tko je taj "netko" ("ona ima doma te kućanske poslove, koje ja izbjegavam, znaš i onak... a ona, hoćeš-nećeš mora... neko mora”).

Cilj muške strategije suradnje je održavanje ravnoteže u partnerskom odnosu prihvaćanjem ženske inicijative da se tradicionalna podjela kućanskih poslova drukčije raspodjeli te odgovaranjem na nju praksama. Ta se strategija pojavljuje u odgovoru na žensku strategiju pritiska i/ili uslijed pritiska strukturnih čimbenika, primjerice, u slučajevima smjenskog rada ili zbog odlaska muškarca u raniju mirovinu (dok žena nastavlja raditi), kao i u slučajevima gdje je žena u partnerskom odnosu više obrazovana, više zarađuje ili ima dulje radno vrijeme. Pritom je moguće razlikovati slučajeve u kojima muškarac preuzima samo jedan kućanski posao, primjerice kuhanje (i to ponajprije kad žena nije kod kuće) od onih u kojima preuzima veći niz kućanskih poslova. U tim razlikama u odabranom načinu "suradnje", vidi se ujedno i razlika između "pomoći” i "ustupaka" (obavljanjem jednog posla) čime

15 Ovdje valja napomenuti da sugovornik ima VSS tehničke struke. 
se zapravo brane ranije postavljene granice "muških" i “ženskih" poslova, u odnosu na "ozbiljnije" preuzimanje niza poslova, koje vodi pomicanju dotadašnjih granica.

Najniži stupanj suradnje ne čini strategiju, nego se pojavljuje u obliku "trenutaka" u kojima muškarci odgovaraju na izraziti pritisak ("kad [žena] poludi”) i obavljaju neki kućanski posao ("dok vidimo da je 'vrag odnio šalu”'). S obzirom na oblik suradnje muškarca, može se govoriti o različitim stupnjevima unutar strategije. Tako se razlikuje: povremeno obavljanje kućanskih poslova kad partnerica to zatraži ("radi kad ga ja natjeram, kad mu kažem: 'sad treba usisat!'”); prihvaćanje preuzimanja dijela redovitih kućanskih poslova ("dok smo mi počeli tu samostalno živjet onda je većina posla bila samo na meni (...) s vremenom i razgovorom je došlo do te podjele - 'ajde ti operi suđe'”); te samoinicirana specijalizacija muškarca za neke kućanske poslove, primjerice preuzimanje obavljanja poslova koji se smatraju manje "ženskima", poput usisavanja ili kuhanja ("bezveze [sam] čekao nju da ona skuva (...) i onda sam ja počeo polako od tih jednostavnijih stvari kuvat, tako da danas kuvam sve"), ili "pomoćnih" kućanskih poslova, poput čišćenja cipela, povremenih velikih pospremanja, slaganja ormara s odjećom ili slaganja namirnica ("moj suprug dosta toga organizira i rješava, da, posebno kad ja odem na neki put, e a onda on obožava napravit spremanje (...) on obožava voditi brigu o cipelama jesu namazane...”).

U način izvođenja muške strategije suradnje može se svrstati i nadomještanje očekivanog obavljanja kućanskih poslova, npr. plaćenom uslugom profesionalne osobe (pri čemu muškarac preuzima barem pola troška ili cijeli trošak). U nadomještanje se može svrstati i to što se muškarac "trudi biti uredan", kao i druge vrste "nadoknade" u svrhu odobrovoljavanja partnerice ili postizanja osjećaja pravednosti u odnosu.

Cilj muške strategije proaktivne egalitarnosti, uz želju postizanja što veće pravednosti u partnerskom odnosu, sadržava i komponentu prepoznavanja lošijeg položaja žene u društvu te želju za širim društvenim promjenama, usmjerenim poboljšanju položaja žena.

Bernard: Ma muškarcima je lakše sigurno. (...) Jer je društvo patrijarhalno. (...) Mislim da se to mijenja, sigurno. A sad, koliko brzo - teško je reć, ali svakako je društvo patrijarhalno još uvijek. (Bernard, 43, veliki grad)

Dražen: Mislim da je lakše biti muškarac, i to u svijetu, a ne samo u Hrvatskoj. Jer žene su manje plaćene za iste poslove, šovinizam je prisutan. (Dražen, 41, veliki grad) 
Sugovornici sa strategijom proaktivne egalitarnosti nisu vidjeli razliku između "muških" i "ženskih" poslova u kućanstvu, točnije rečeno proaktivno su negirali bilo kakvu rodnu razliku među njima.

Bernard: Ne postoje muški i ženski poslovi (...) ne postoji ta vrsta podjele. (Bernard, 43, veliki grad)

Uz načelno brisanje granica između "muških" i "ženskih" poslova, način izvođenja te strategije pokazuje se i u pokušajima da se prakse u obavljanju kućanskih poslova što više približe načelu "tko šta stigne obaviti" te da se individualna zaduženja dogovore po preferencijama ("on više pegla nego ja jer voli više peglat nego ja"). Isto vrijedi i za brigu o djeci, odnosno emocionalni rad koji obavlja i muškarac.

Pitanje: Što tebi osobno znači briga za dijete? Jurica: Užasno puno. (...) sad je taj period, u ovom periodu se gradi povezanost s djetetom, koja ostaje do kraja života. A ako to sad preskočim, to se neće moći razviti kasnije u većoj mjeri. (Jurica, 38, veliki grad)

Muškarci sa strategijom proaktivne egalitarnosti spominjali su podjelu rada svojih roditelja kao egalitarniju nego kod drugih, ili, pak, poduku o poželjnosti obavljanja kućanskih poslova da sve ne bude "na teret žene":

Emil: ...svakako su se trudili što više me pogurati $i$ naučiti da me oforme od malena kao samostalnu osobu. (Emil, 25, veliki grad)

\subsection{2. Ženske strategije}

$U$ individualne ženske strategije ubrajaju se strategije neupitnosti, pritiska, pristajanja, te proaktivne egalitarnosti.

Cilj ženske strategije neupitnosti, sukladan cilju istoimene muške strategije, održavanje je tradicionalne podjele kućanskih poslova i tradicionalnog rodnog poretka. Razlika u odnosu na muškarce jest u tome što žene tu strategiju manje iniciraju, a više se u nju uklapaju. Kao i kod muškaraca, važni su elementi pozivanje na tradiciju, socijalizaciju, rodni poredak i rodni esencijalizam. Tradicionalna podjela poslova shvaća se kao "normalna" i "jasna”, počevši od rodne socijalizacije pa do trenutačnih partnerskih odnosa.

Pitanje: Očekivanja roditelja od Vas (...)? Blanka: Normalno, oko blaga, da mogu mami pomoć skuvat, da joj mogu oprat, da joj mogu očistit. Da znam kopat... Danas-sutra, šta bi reka, da se ne stide, da ne odeš, a da ništa ne znaš. (Blanka, 49, selo) 
Kod žena sa strategijom neupitnosti, kućanski poslovi su dio identiteta, kao što se i vještine izvođenja mnogih sitnih praksi smatraju "prirodnima" ili eventualno duboko "ugrađenima" ("nešto ti vjerojatno ko mehanički usađeno u tebe").

Među intervjuiranim ženama, strategija se češće pojavljuje na selu te kod niže obrazovanih sugovornica, iako je zabilježena i kod pojedinih žena starije dobi u gradu:

Lepa: Ja sam obavljala jako puno, on je... malo više bio onako nježniji i to. Ali nije bilo nikakvih poslova za posebno obavljati (...) on je voleo ležati lepo i čitati i tak, našao si je komociju, da. (...) on se više $i$ šetao i... tako, s dečkima... A ja sam ostajala kod kuće... pauke pobrati... (...) muž se nije s tim bavio, niti oprati, popeglati dijete, obući, srediti, on je dobio dijete gotovo za rukicu i ono... u šetnju. (Lepa, 81, grad)

Nadalje, važnom se pokazuje uloga svekrve, pogotovo u seoskim kućanstvima u kojima je ona oblikovala život mladoj ženi, dok je muškarac radio izvan kućanstva ("a ona [svekrva] bi uvijek: 'ti imaš malu djecu, ti ostani u kući, pazi dicu, skuvaj ručak, očisti kuću!'”).

No, valja dodati da su žene ponekad preuzimale i "muške" poslove izvan kućanstva, primjerice, u proizvodnji za vlastite potrebe ili za prodaju (poljoprivreda), što se također smatralo neupitnim ("nekad kad muža nema kući, ja moram napravit i njegov dio posla i svoj... 'nema'... i tako je to bilo").

Životi žena svrstanih u strategiju neupitnosti izrazito su usmjereni na kućanstvo, brigu za djecu i život u kući, čak i kad obavljaju plaćene poslove izvan kuće. Unatoč već oslikanoj neupitnosti podjele, u nekim je intervjuima bilo moguće mikroetnografski uočiti unutarnje žaljenje zbog svakodnevnog "prešutnog pristajanja" na rodni poredak koji nameću muškarci.

Cilj ženske strategije pritiska je pokušaj promjene tradicionalne podjele kućanskih poslova i time promjene tradicionalnih rodnih uloga. Načini izvođenja te strategije su različiti oblici prigovaranja zbog neprovođenja kućanskih poslova, kao i zahtijevanje da se obave povremeni kućanski poslovi poput pospremanja ili usisavanja ili svakodnevni kućanski poslovi poput pranja suđa ili stavljanja suđa u perilicu. Pritom nekim muškarcima treba govoriti "dosta često":

Pitanje: ...koliko često mu trebate reći? Anita: Dosta često. Alen: Dosta često.

Pitanje: Koliko je to dosta često? Anita: Ne znam, koliko ćemo reći? Alen: Svako jutro, ha ha ha. (Alen i Anita, 47 i 40, selo) 
Pojavljuju se i pokušaji povećavanja kvalitete muškog obavljanja kućanskih poslova ("ako ga zamolim da nešto napravi, onda da napravi kako treba", "ja sam opet išla za njim, to on kao pere kupaonu, ali to nije to, to je... ja dosta prigovaram, dosta prigovaram") kao i pomicanja postojećih rodnih granica trajnijim dodjeljivanjem kućanskih poslova muškarcu:

Mara: Mi smo morali jedan na jednu smjenu, drugi na drugu smjenu, ne? Ja bi jutro, on popodne. Radi dečeca, kaj je moral učiti, ne? I... onda je on moral početi kuhati... a ima volju kuhati. Rado kuha, tak da... A on i sve ostale poslove. Kaj bi mene to sve čekalo kad bi došla doma?! - super [ironično, opaska autora]! (Mara, 38, selo)

Važno je napomenuti da dio žena kao ispunjenje svoje strategije pritiska vidi i niži stupanj sudjelovanja (povremeno sudjelovanje) te smatra da je dostatan pomak kad se muškarac u kućanstvu nauči "pomagati" ("ako vidi da ja nisam u mogućnosti”), pogotovo s obzirom na potpuno asimetričnu raspodjelu u generaciji roditelja.

S druge strane, neke žene zahtijevaju i očekuju veći stupanj sudjelovanja. Važno je napomenuti da je u izjavama dijela žena unutar praksi koje odgovaraju strategiji pritiska uočena i izražena potpora promjenama praksi kod muškarca.

Ženska strategija pristajanja predstavlja odustajanje od cilja pokušaja promjene tradicionalne podjele kućanskih poslova i time promjene tradicionalnih rodnih uloga unutar partnerskog odnosa. Ta je strategija stoga pasivnijeg karaktera i može se iščitati, primjerice, iz izjava koje izražavaju pristajanje na teret obavljanja kućanskih poslova, što prati umanjivanje njihove zahtjevnosti ("meni su ti kućanski poslovi jednostavni jer ih mogu brzo obaviti").

Pojavljuje se i umanjivanje važnosti kućanskih poslova koje sugovornice obavljaju, u usporedbi s "muškim" poslovima:

Jagoda: Pa mislim da bi mi bilo lakše kućanski poslovi, nego da idem u šumu drva vleči i piliti. (...) on obavlja [posao] vani, koji je više i fizički teški, koji ja taj dio ne bi mogla odraditi. (Jagoda, 39, selo)

Na pristajanje na obavljanje kućanskih poslova koji se smatraju izrazito "ženskima", nailazi se i kod obrazovanih žena s dominantnom radnom ulogom u partnerskom odnosu, odnosno u kućanstvima u kojima je muškarčeva karijera sekundarna i gdje on pristaje na suradnju u obavljanju značajnog dijela kućanskih poslova:

Laura: Ja imam veći prihod, da, i to duplo veći prihod (...) Unutar naše kuće naravno ja perem, stavljam veš u perilicu, peglam, mijenjam posteljinu (...) u našem društvu muškarac ima tu ulogu, taj osjećaj da mora bit kao zaposlen i da 
se mora brinuti o obitelji i mislim da oni nisu dovoljno fleksibilni da se prilagode nekoj drugoj ulozi. (Laura, 47, grad)

Primjetno je i žensko umanjivanje ili prešućivanje razmjera asimetričnosti u rodnoj podjeli rada. Ponekad sugovornice navode da podjela kućanskog rada nije rodno diferencirana, iako već i u intervjuu izneseni podatci govore suprotno:

Štefica: Ko šta stigne, taj radi. Vrlo kratko i jasno... Slavek: Pa nije baš tak... (Slavek i Štefica, 57 i 53, selo)

Drugi oblik umanjivanja ili prikrivanja neegalitarnosti u partnerskom odnosu jest naglašena identifikacija sa sferom kućanstva, osobito kroz brigu za djecu dok su mala.

Mara: Meni puno znači da sam ja s njima doma, ne? (...) baš zbog njih... zbog djece, ne? (Mara, 38, selo)

Valja, na koncu, napomenuti da kod žena sa strategijom pristajanja postoje dva različita načina ulaska u tu strategiju. Prvi od njih jest odustajanje od prethodne strategije pritiska (što mogu pratiti mikroetnografski uočljive emocionalne komponente rezigniranosti i nezadovoljstva):

Štefica: Kaj, kaj bi mijenjala, kaj imam mijenjati (...) svak je individua za sebe $i$ ne mreš ti tu nekaj mijenjati. (Štefica, 53, selo)

Drugi način ulaska u strategiju pristajanja jest to što se na temelju nje konstituira ukupan rad kućanstva i partnerski odnos, što je zabilježeno, primjerice, u nekim od slučajeva kad muškarac provodi više vremena od žene na plaćenom radu i/ili zarađuje znatno više:

Dunja: On dođe doma zdrobljen oko 10 sati i ja nemam nikakvu potrebu njemu govoriti: 'mogao si ovo'. (Dunja, 43, grad)

Cilj ženske strategije proaktivne egalitarnosti jest postizanje što veće pravednosti u odnosu, kao i širih promjena u društvu usmjerenih na poboljšanje položaja žena. Može se reći da je u ovome identična deklariranim intencijama istoimene muške strategije, no uz tu razliku da žena govori iz položaja vlastitog iskustva rodne diskriminiranosti te pripadnosti rodno diskriminiranoj skupini.

Kod sugovornica s ovom strategijom pojavljuje se motiv traženja egalitarnog partnera ("neki normalni čovjek koji nije mamin sin, ono... pa da ga ja moram 
usluživat"), ali i briga za položaj drugih žena te za rodnu pravednost općenito ("feministica [sam] stara").

Jedna sugovornica spominje i rodnu socijalizaciju u feminističkom duhu:

Greta: [Majka] nas je uvijek pokušavala odgajati u tom nekom feminističkom... ženska prava, žene i tako dalje... pokušala nas je izučiti da žena mora biti samosvjesna (...) da se mora znati izboriti za sebe. (Greta, grad, 40)

Sugovornice u ovoj strategiji od partnera očekuju ravnopravno sudjelovanje u obavljanju kućanskih poslova:

Lorena: Radimo sve. Pitanje: Kako ste podijeljeni? Lorena: Nema podjele. (Lorena, 39, veliki grad)

Greta: U našem kućanstvu svi sve radimo, kod nas je stvarno lijep odnos. (...) Pitanje: Kako je došlo do te raspodjele? Greta: Pa ne znam, sasvim prirodno. (Greta, grad, 40)

Potonja se izjava može povezati s motivom traženja (i uspjehom u nalaženju) egalitarnog partnera, o kojem je sugovornica govorila ranije u intervjuu, a s kojim je onda "prirodno" došlo do egalitarne podjele kućanskih poslova. No, valja naglasiti da je proaktivno djelovanje na postizanju veće rodne ravnopravnosti moguće i kod žena koje nisu uspjele pronaći egalitarnog partnera ili se nisu uspjele u partnerskom odnosu izboriti za egalitarnost u podjeli kućanskih poslova.

U takvim slučajevima, riječ je o "tihom” promicanju egalitarnosti “odozdo”, kojoj je cilj povećanje rodne ravnopravnosti u sljedećoj generaciji, usmjeravanjem rodne socijalizacije vlastite djece prema ravnopravnijim rodnim praksama:

Klara: Budem ga [petogodišnjeg sina] odgajala u budućnosti da se je zna, to bude mi prvo - da zna raditi kak žensko, da se zna brinuti o sebi-jer, kak budu životni putovi, bude mu to jako puno koristilo i da, ovoga, se zna kak ponašati prema ženi, to... to su mi dve najvažnije stvari. (...) On se mora ponašati prema ženi kao da je jednaka njemu, a ne: 'ti si žensko, ti si manje vrijedna'. (Klara, 41 , selo) 


\subsubsection{Komponenta opravdavanja u individualnim strategijama}

U individualnim muškim strategijama otpora i suradnje, kao i u individualnim ženskim strategijama pritiska i pristajanja, nailazi se na izjave kojima se pokušava opravdati vlastite i/ili partnerove/icine prakse u podjeli kućanskih poslova. ${ }^{16}$

Muškarci opravdavanjem (tj. različitim izgovorima) nastoje objasniti vlastito nesudjelovanje ili nedovoljno sudjelovanje u obavljanju kućanskih poslova. Važno je primijetiti da svaki takav izgovor, osim što svjedoči o nezadovoljavanju zahtjeva partnerice, također upućuje na neki oblik izloženosti pritisku rodno egalitarne norme te svijest o tome da je sugovornici ne zadovoljavaju.

Neka su muška opravdanja pritom "konkretna” (“Ja!? Po kruh? A oni? Oni da leže, a da im ja kruh donosim!?”), a druga koriste argumente iz kulturnog repertoara rodnog esencijalizma, poštovanja tradicije i/ili načina vlastite rodne socijalizacije:

Bojan: Kuhanje, to ispada ko da joj je urođeno, ne? Nije muškarcima to tolko, ne? (Bojan, 55, mali grad)

Nailazi se i na usporedbe s drugim, "gorim" muškarcima (među rodbinom i prijateljima, ili općenito u susjedstvu), za koje se navodi da u kućanstvu rade još manje te da je njihov odnos prema partnerici još lošiji:

Slavek: Ima puno gorih od mene, kaj baš... ja ti bar sude operem, ${ }^{17}$ primjer $t i$ velim, ne? (...) al drugi muž, kad je on išel sud oprat pored žene ili kćeri doma... nema šanse, razmiš? (...) Ja nisam takav. (Slavek, 57, selo)

Bilježi se i muško pozivanje na rodne razlike, prema kojima se žene navodno manje umaraju pri kućanskim poslovima i sposobnije su ih brže i bolje obaviti ("ona je stalno u akciji tako da... (smijeh) teško pratit!"), kao i pozivanje na vlastiti nedostatan kapacitet da se toliko "konstantno" radi ("ona uvijek nešto radi, ja kad dođem doma ja se najedem, pa se onda sjednem, pa... pa gledam televiziju, znam se odmarat...").

Dio opravdavanja je i isticanje važnosti "pomoći” i "ustupaka" koje muškarac čini obavljanjem "ženskih" poslova u kućanstvu ("sad imam vremena, pa onda ajde odradiš koji ženski posao... mislim ženski... ženski-muški, ne?").

16 Te su izjave ponekad toliko učestale da bi se moglo činiti da je riječ o zasebnoj strategiji (utemeljenoj upravo na opravdavanju). Međutim, prakse koje te izjave opisuju su ipak tek komponenta različitih strategija, stoga što koncept "strategije" podrazumijeva obrazac ili "logiku" nizanja praksi, a u tim je slučajevima riječ tek o primjerima opravdavanja praksi koje se mogu umetati u više različitih strategija.

17 Ovdje valja napomenuti da Slavekova supruga Štefica praktički uvijek pere suđe. 
Navodi se, na koncu, i to da muškarci ne obavljaju kućanske poslove da bi se mogli usredotočiti na plaćeni rad:

Bojan: Muški očekuju od žena ove kućanske poslove. (...) ak ostane bez toga, onda kao muški ne može svoje planove sprovesti (...) da sam ja morao dijete oblačit, vozat i ovo... nema od toga sreće, ne? Ovo je ipak neki ekipni rad, ne? (Bojan, 55, mali grad)

Dio se ženskih opravdavanja pojavljuje kao zrcalna slika muških. Pozivaju se, naime, na slične argumente, primjerice o tome da je njihov partner "bolji (...) od ostalih" ili da one "posao mogu obaviti brže", jer su žene sposobnije za obavljanje kućanskih poslova.

Razlika je, međutim, u tome što su u središtu opravdavanja ovdje ponovo "nerad" muškarca te njegovi uzroci, a ne vlastite prakse. One se spominju tek u mjeri u kojoj žene pokušavaju opravdati svoj asimetričan doprinos kućanstvu.

Druga je razlika u tome što se u muškim narativima manje jasno navodi čemu valja pripisati navodne razlike u sposobnostima muškaraca i žena za obavljanje kućanskih poslova ("prirodi”, "odgoju”, "navici” ili individualnim karakteristikama). U ženskim se, pak, narativima uzroci pokušavaju ipak jasnije specificirati:

Jelena: Meni je možda lakše taj dio odraditi, nekak to od malena kak su nam usadili, to dalje tak se i ponašamo. (Jelena, 46, veliki grad)

Lana: ...zato što smatram da muško ne može napravit nešto što može žensko... nije ni precizan ko žensko (...) napravit će to tako ofrlje ili... kako da vam objasnim... onako kako zna, ali zapravo ne zna dovoljno dobro ko žensko. (Lana, 33, selo)

Dunja: Žene su spremnije a možda su i genetski sposobnije za to da više stvari istovremeno odrade... (Dunja, 43, grad)

Kao što se vidi iz navedenih izjava sugovornica, i u njima se kombiniraju različiti načini opravdavanja, pri čemu su kombinacije različitih izvora vlastitog ponašanja i praksi ponekad slični onima u muškaraca, pa i posve sukladni.

Uočena je i ženska komponenta opravdavanja kojom se zapostavljanje karijere i preuzimanje kućanskih poslova obrazlaže brigom za djecu (pogotovo novorođenčad i malu djecu).

Nikolina: Ja bi samo malo više vremena, al to otkad je [ime kćeri] tu, nemam tog vremena (...) da imam više vremena za napredovanje u struci (...) imam ja sad i nekakve možda feminističke nazore i to, al što se tiče toga [obavljanja kućanskih poslova], nije mi to problem... (Nikolina, 41, prigradsko naselje) 


\subsection{Strategije kućanstava u podjeli kućanskih poslova}

Dovođenjem u odnos prikazanih muških i ženskih individualnih strategija, ${ }^{18}$ promatranih na pozadini ukupnog rada kućanstva uz primjenu kriterija "rodne ravnoteže" (integriranog u analizu iz teorije), dobiveni su sljedeći tipovi strategija kućanstava u podjeli kućanskih poslova: neupitno tradicionalna, pretežno tradicionalna, početno egalitarna, te proaktivno egalitarna.

Neupitno tradicionalna strategija kućanstva temelji se na supostojanju i kompatibilnosti muške i ženske individualne strategije neupitnosti u podjeli kućanskih poslova. Između tih dviju strategija ne odvija se sukob: one se dopunjavaju kroz suradnju, odnosno potiču jedna drugu. Pretpostavka je te strategije da muškarac obavlja rad koji odgovara funkciji "hranitelja obitelji" ili pak ima drugi izvor prihoda koji omogućava spomenutu poziciju, poput mirovine. To mu omogućava pozivanje na vlastito neupitno mjesto u tradicionalno shvaćenom rodnom poretku.

Žena obavlja gotovo sve kućanske poslove (uključujući i mnoge "oko kuće"), ne radi izvan kućanstva za plaću ili se - ako radi - njezin plaćeni rad doživljava kao "sekundaran" u odnosu na partnerov i na "njezine" kućanske poslove. Uz rad u kućanstvu te (u nekim slučajevima) izvan kuće za plaću, žena u toj strategiji obavlja i velik dio rada u proizvodnji za vlastite potrebe - primjerice u poljoprivredi i proizvodnji hrane:

Ankica: Tako ja sam onda preuzela štalu i s time se bavila... ko sad drugi posao. (Ankica, 50, selo)

Da bi ostvarili ulogu "primarnog hranitelja" u doslovnom i simboličkom smislu (odnosno da bi mogli, s jedne strane, dovoljno zaraditi, a s druge zadovoljiti očekivanja od uloge), dio muškaraca u toj strategiji povećava intenzitet i količinu plaćenog rada na formalnom ili neformalnom tržištu, kao i stres koji s tim povezuju, ponekad do granica ozbiljnog ugrožavanja zdravlja:

Ante: Ja sam preživio dva infarkta (...) ona to drukčije, drukčiji sistem gleda nego ja, čovjek je samozatajniji $i$ u sebi to non-stop nosi, nosiš nešto, sav taj teret $i$ u životu i sekirancije i kako sutra... (Ante, 44, selo)

18 Izravan susret individualnih strategija muškaraca i žena bio je vidljiv u provedenim partnerskim intervjuima. No, s obzirom na relacijski karakter strategija i konstrukciju protokola, iz podataka prikupljenih svakim individualnim intervjuom također je bila vidljiva i strategija partnera/ice. Teorijski okvir primijenjen u analizi odnosio se ponajprije na Bourdieuov prakseološki pristup strategijama, koji podrazumijeva da empirijski zasićena analiza rezonira s društvenom strukturiranošću različitih polja i otkriva logiku praksi koje se u njima odvijaju. 
S druge strane, muškarci koji - uslijed kompatibilnosti različitih strukturnih čimbenika sa svojim radnim biografijama - uspijevaju ostvariti ulogu "primarnog hranitelja” bez većeg napora, žive znatno lagodnije od partnerica. Čak i kad (npr. nakon odlaska u mirovinu), povećaju svoj doprinos proizvodnji za vlastite potrebe, imaju prostora za vlastite aktivnosti i ne sudjeluju u kućanskim poslovima, dok ženin radni dan ne prestaje sve dok u kućanstvu ima posla.

Kao i kroz ranije opisivane individualne strategije neupitnosti, kroz ovu se strategiju kućanstva održava tradicionalni rodni poredak, odnosno mjesta muškarca i žene u njemu. Žene koje neupitnim stavom o podjeli rada podržavaju tu strategiju kućanstva, uz prešućivanje i umanjivanje teškoća kroz koje prolaze, svoju refleksiju o toj situaciji ponekad izražavaju kao žaljenje:

Ankica: I nekako ženski rod... nekako uvik mi je žao... Pitanje: A zašto? Ankica:

Pa šta ja znam. Kućanski poslovi... to je puno posla koji se ne vidi kao posa. Puno imaš posla, a on se u biti... ti kad i napraviš to, to ti se... niko to ne vidi da si ti... a muški, to... oni šta rade vani... sad ti to vidiš šta su oni napravili. (Ankica, 50, selo)

Pretežno tradicionalna strategija kućanstva temelji se na sukobu individualne muške strategije otpora promjeni (odnosno preuzimanju kućanskih poslova) sa ženskim strategijama pritiska i pristajanja. Pretpostavka ove strategije kućanstva jest da žena želi mijenjati postojeću podjelu kućanskih poslova, ali u tome ne uspijeva u većoj mjeri: muškarac ipak - barem povremeno - obavlja neki kućanski posao, jer je uvijek pod nekim oblikom pritiska da ga počne obavljati.

Tatjana: Pa ja bih recimo voljela da on nekako više i da malo bolje i kvalitetnije sudjeluje u tome svemu (...) Pitanje: Vi njemu morate reći svaki put? Tatjana: Da, moram. (smijeh) (Tatjana, 28, prigradsko naselje)

Kod žena se, pak, unutar te strategije izmjenjuju i/ili miješaju strategije pritiska i pristajanja, ovisno o ishodu sukoba s muškom strategijom otpora. Međutim, jasno je da ovdje više nema povratka na neupitno tradicionalnu strategiju niti na odnose koje ona podrazumijeva: uz više ili manje izraženo nezadovoljstvo žene, može doći jedino do smanjivanja ili pak pojačavanja pritiska da kod muškaraca dođe do promjene.

Muškarci - pogotovo oni u radničkim, nesigurnim i slabije plaćenim zanimanjima - čiji je položaj "primarnog hranitelja" doveden u pitanje uslijed promjene strukturnih ekonomskih čimbenika, taj položaj nastoje osigurati dodatnim plaćenim radom na formalnom ili neformalnom tržištu: 
Juraj: Ali dok će se žena baviti kućanskim poslovima, sa djecom (...) za to vrijeme muž će još možda honorarno zaradit... ono, još zaradit dodatna sredstva, dodatni rad i sposobnost... (Juraj, 56, mali grad)

Drugi način osiguravanja poljuljanog položaja "primarnog hranitelja" jest obavljanje većeg dijela rada u proizvodnji hrane za kućanstvo (ili prodaju) te u obavljanju poslova vezanih uz kuću, koji inače iziskuju značajan potrošak novca. Takvi građevinski poslovi, kao i različiti popravci i adaptacije, ponekad se pružaju i prijateljima i susjedima, koji in kasnije na različite načine uzvraćaju.

Martin: Ja sam dosta dugo tu držao tri ugla kuće. Ženo jel se slažeš ti s tim? Mara: Da, dok smo kuću delali. (Mara i Martin, 38 i 41, selo)

Matija: Tu šta god vidiš, zgradu donju i u brdu vikendicu to sam ti ja sve sam zidao i sam napravio. (...) Svima hoću pomoć, uradim sve, recimo, ovoj komšinici neki dan sam pola kuće instalaciju napravio. (...) A i te bašće, to puno zahtijeva svaki dan (...) svaki dan moraš biti tu, isto kao gore kad smo vinograd imali, svaki dan treba raditi. (Matija, 66, grad)

U nekim je slučajevima takav rad važan za preživljavanje kućanstva, a u drugim slučajevima ga se muškarci prihvaćaju i stoga što ih on "udaljava" od kućanskih poslova.

Za razliku od kućanstava s neupitno tradicionalnom strategijom, žene u kućanstvima s pretežno tradicionalnom strategijom često su bile zaposlene, i to na lošijim poslovima nego muškarci. Ako pak nisu imale stalan plaćeni posao, radile su na sezonskim plaćenim radovima u poljoprivredi ili sitnim formalnim i neformalnim poslovima povremenog karaktera (primjerice usluge čišćenja ili ispomoći u restoranima).

U pretežno tradicionalnu strategiju valja svrstati i kućanstva u kojima muškarac nema poziciju "hranitelja" (primjerice, nezaposlen je ili umirovljen, a žena ima veći prihod), no unatoč tomu ne provodi nikakve dodatne radne aktivnosti: na žensku strategiju pritiska i dalje odgovara strategijom otpora te tek nižim razinama suradnje (poput povremenog kuhanja).

Milena: Pa ja idem radit, on nema lipe Isusove već godinama, ništa... (...) Mićo: Al kažem i ja dan-danas kuham i... e, samo što suđe ne perem. To mi je mrsko... (...) ništa nije "pod mus" (...) Milena: Pa dobro, pa da... čišćenje, pranje veša tako to... što žene rade... (Mićo i Milena, 59 i 55, grad) 
Za razliku od pretežno tradicionalne strategije kućanstva, u kojoj ženska individualna strategija pritiska nailazi na mušku individualnu strategiju otpora, kod početno egalitarne strategije kućanstva, na žensku strategiju pritiska muškarac odgovara strategijom suradnje. U takvim kućanstvima, dio sugovornica zadovoljan je već i time što muškarac bez većeg otpora preuzima dio kućanskih poslova i trudi se "pomagati":

Pitanje: Jeste zadovoljni s takvom podjelom? Lada: Jesam, jesam, zato što (...) ne osjećam da je sve na meni (...) sad ako ne pokupim čaše sa stola, ja te čaše kad dođem kući neću zateći jer on će ih maknut.(...) da ja baš te stvari moram napravit sama, onda bi mi to bio problem. (Lada, 33, selo)

Uslijed ženskog pritiska i, u dijelu slučajeva, strukturnih čimbenika (smjenski rad, jednako ili bolje plaćeni posao, jednak ili viši radni status, dulje radno vrijeme), muškarci u takvim kućanstvima preuzimaju dio kućanskih poslova. Taj je dio svakako značajan u odnosu na pretežno tradicionalna kućanstva, međutim granica se uglavnom ipak ne pomiče na redovito obavljanje poslova koji se smatraju najviše "ženskima" (glačanje, čišćenje kupaonice, pranje rublja).

U početno egalitarnim kućanstvima, muškarci nastoje zadržati ulogu "primarnog hranitelja" (u nekim slučajevima obavljajući i već opisani dodatni rad), ali u njima nije upitno da žena radi izvan kuće za plaću te da se po statusu i plaćenosti posla može sasvim približiti muškarcu ili ga preteći. Među intervjuiranima koji pripadaju toj strategiji, više nego u prethodnoj - pretežno tradicionalnoj - pojavljivala su se kućanstva u kojima žene uz regularni posao rade dodatne plaćene poslove ili, u situacijama mirovine ili nezaposlenosti, imaju povremene formalne i neformalne poslove.

Max: [Supruga] pomaže, kad treba uskoči, i tako, kumi - ona ima vrtiće i centar za vjenčanja (...) čišćenje, peglanje, dekoriranje (...) I ona kaže: "ja bi išla radit" - "pa ako oćeš idi radit, ja neću, ja sam svoje odradio". (...) Tak da sad kuham, nije mi problem spremit, oprat prozore. (...) Božena: Dok ja radim, naravno, preuzme obavezu i trgovine i usisat $i$... i ja mašinu pripremim, on to sve odradi... (Max i Božena, 61 i 58, grad)

Ipak, u kućanstvima unutar te strategije, muški plaćeni rad i karijera još se uvijek smatraju važnijima, a uloga žene vidi više u kućanskim poslovima (uključujući i brigu o djeci i starijima).

Za razliku od prethodne (početno egalitarne), kod strategije proaktivne egalitarnosti do pomaka dolazi ponajprije iz rodne ideologije partnera/ice, a manje iz praksi. Kad je riječ o "ideologiji”, valja napomenuti da ona ovdje više nije u područje 
borbe, jer je ostvarena sukladnost partnera i partnerice. U središtu je stoga dogovor oko preuzimanja pojedinih oblika kućanskog rada.

Ako u takvom kućanstvu muškarac ostvaruje nešto nalik poziciji "primarnog hranitelja" (donosi znatno više novca ili ima viši status zaposlenja), on ne ističe simboličku stranu te uloge niti je koristi za ostvarivanje prevlasti u partnerskom odnosu. Isto vrijedi i za ženu, u situaciji kad ona - inverzno - preuzima poziciju "primarnog hranitelja".

Unatoč zahtjevima plaćenog rad izvan kuće, muškarci ovdje nemaju ograda prema obavljanju kućanskih poslova, uključujući i brigu za djecu te izraženu komponentu emocionalnog rada. Kućanski se poslovi obavljaju po načelu "tko što stigne" i prema preferencijama, bez postavljanja granica u smislu "muških" i "ženskih" poslova:

Bernard: Ne postoje muški i ženski poslovi (...) ne postoji ta vrsta podjele. Lorena: Uopće ne razgovaramo na toj razini. (Bernard i Lorena, 43 i 39, veliki grad)

Za razliku od početno egalitarnih, u tom tipu kućanstva žene ne postavljaju sebi ograničenja u napredovanju u karijeri zbog preuzimanja većeg tereta kućanskog rada i brige o djeci. Također, ne "odobrovoljavaju” muškarca koji obavlja neke kućanske poslove ili je statusom slabiji od njih. Egalitarnost se očekuje od obiju strana u odnosu i u svim vrstama poslova (uključujući i honorarne i druge dodatne poslove):

Dražen: Mislim da je isključivo vrijeme faktor, a vrijeme je povezano s novcem, tako da ona više zaradi, pa onda je bolje da imamo više novaca, tako da ja radim one poslove koji nisu plaćeni. (Dražen, 41, veliki grad) 


\section{RASPRAVA}

Nakon provedenoga kvalitativnog istraživanja čiji su rezultati početno prezentirani u ovom članku, možemo znatno detaljnije i podatkovno bogatije raspravljati o rodno diferenciranim individualnim strategijama u podjeli kućanskog rada, kao i različitim tipovima kućanstava s obzirom na rodnu ravnotežu u obavljanju kućanskih poslova.

Promatrajući dobivene tipove kućanstava, možemo ustvrditi da u dvama od njih, krajnje različitima $s$ obzirom na rodnu ravnotežu (neupitno tradicionalnim i proaktivno egalitarnim), nema sukoba individualnih strategija partnera/ice, stoga što su strategije u njima uglavnom u suglasju i međusobno se potiču.

$\mathrm{U}$ drugim dvama tipovima kućanstava (pretežno tradicionalnim i početno egalitarnim), rodno diferencirane individualne strategije u kućanstvu oblikovane su, pak, kao svojevrstan susret moći i protumoći. Suprotstavljenost individualnih muških i ženskih strategija u takvim kućanstvima dovodi do sukoba, čije razrješenje dovodi do dinamičke ravnoteže u partnerskom odnosu. Kad sukob dovodi do promjena, to znači da se u partnerskom odnosu ostvaruje suradnja, ili da se barem privremeno pomiče granica rodne asimetričnosti u obavljanju kućanskih poslova. No, sukobi također mogu voditi i do otpora promjenama, što potencijalno vodi do novih sukoba.

Promjene u podjeli kućanskih poslova u pretežno tradicionalnim i početno egalitarnim tipovima kućanstva potaknute su promjenama strukturnih čimbenika praćenim ženskom inicijativom ili obratno, ženskom inicijativom (temeljenom na početno egalitarnoj rodnoj ideologiji), koju podržavaju promjene strukturnih čimbenika. U tim se dvama tipovima kućanstva, dakle, događa stanovita promjena rodnih odnosa, pri čemu su mogući različiti ishodi: s jedne strane, pomak prema više egalitarnosti, ili pak povratak na "pretežnu" (ali ne i "neupitnu") tradicionalnost.

Važno je naglasiti da inicijativa za promjenom u tim dvama tipovima kućanstva potječe od žene i njezine želje za promjenom postojećeg stanja. Muškarci, dotle, oslanjajući se na elemente pretežno tradicionalne rodne ideologije (koje koriste kao resurs u strateškoj borbi), na ženin pritisak mogu odgovoriti strategijom otpora te tako "vući natrag" u tradicionalizam. No, valja spomenuti i to da se i kod žena pri primjeni (egalitarno motivirane) individualne strategije pritiska - mogu pojaviti elementi pretežno tradicionalne rodne ideologije (stečene npr. rodnom socijalizacijom). Oni mogu dovesti do toga da neke od njih kroz individualnu strategiju pristajanja sudjeluju u povratku ili zadržavanju elemenata tradicionalnoga rodnog poretka.

Pokazuje se da su prema više egalitarnosti u odnosu samoinicijativno spremni ići samo muškarci u proaktivno egalitarnim kućanstvima, kod kojih je već postignuta znatna prethodna promjena. Pokazuje se također da se - uz "svjesne" i "nesvje- 
sne" komponente strategija - mogu razlikovati i "aktivnije" i "pasivnije" strategije, pri čemu su ženske strategije najčešće "aktivnije" od muških.

Kako bilo, jasno je da se promjena (na razini kućanstva) odvija kroz borbu pritisaka i otpora, te pritisaka i suradnje, odnosno "igrajući igru" i "vukući poteze" (Bourdieu i Wacquant, 1992: 99) s ulozima koje partneri/ce imaju na raspolaganju i izražavaju u svojim individualnim strategijama, pozivajući se na specifične sastavnice egalitarne ili tradicionalne rodne ideologije, kao i na opravdanja u smislu resursa koje donose u kuću te vremena koje im ostaje nakon plaćenog rada. Za daljnja proučavanja vrlo je poticajna "komponentna opravdavanja" na koju se osobito često nailazi u tipovima kućanstava kojima je rodna ravnoteža u procesu promjene. Valja, međutim, naglasiti da je načine argumentiranja muškaraca i žena potrebno detaljnije istražiti u svim tipovima kućanstava, a ne samo u onima u kojima sukobljenost individualnih strategija muškaraca i žena upućuje na to da su u procesu transformacije. Osobitu bi pozornost pritom valjalo posvetiti proaktivno egalitarnim kućanstvima, s obzirom na to da je u literaturi zabilježena i praksa "egalitarnosti na riječima" (Lyonette i Crompton, 2015: 37).

\section{ZAKLJUČAK}

U ovom članku prikazane su analizom identificirane individualne strategije muškaraca i žena povezane s obavljanjem kućanskih poslova. Kod muškaraca su to strategije neupitnosti, otpora promjeni, suradnje, te proaktivne egalitarnosti, a kod žena strategije neupitnosti, pritiska, pristajanja, te proaktivne egalitarnosti. Dovođenjem u odnos spomenutih muških i ženskih individualnih strategija, uz primjenu kriterija rodne ravnoteže, dobivena je tipologija strategija kućanstava (s obzirom na podjelu kućanskih poslova), prema kojoj se ona dijele na: neupitno tradicionalna, pretežno tradicionalna, početno egalitarna i proaktivno egalitarna.

Heurističkim doprinosom u članku prikazanog istraživanja, provedenog u skladu s načelima Bourdieuove "logike otkrića" (Krais, 1991: vi), smatramo to što je ono - uz izgradnju navedenih tipologija - rezultiralo i bogatim opisom suradnji i sukoba muškaraca i žena povezanih s kućanskom podjelom rada.

Teorijsko-metodološki doprinos članka u tome je što se pokazalo da je odabrani analitički okvir - inspiriran konceptom strategija u Bourdieuovoj prakseološkoj teoriji - prikladan za kompleksnu analizu relacijskih rodnih odnosa. U prvom redu, njegova je primjena omogućila analizu logika nizanja praksi muškaraca i žena unutar istog kućanstva. Isto tako, pokazalo se da je odabrani pristup u stanju zahvatiti dinamiku promjena u kućanstvima ne samo u "internim" (podjela kućanskih poslova) nego i u "eksternim" dimenzijama (doprinos drugih vrsta rada u ukupnom radu 
kućanstva). U tom smislu, kvalitativna analiza poduzeta u ovom članku otvara put daljnjem uključivanju rodne dimenzije u širi model analize društvenih nejednakosti.

Kad je riječ o ograničenjima odabranog (bourdieuovskog) pristupa, ona se ponajprije odnose na potrebu provedbe većeg broja kompleksnih analiza, koje takav pristup zahtijeva. lako smo u razmatranju teme uzeli u obzir spoznaje svih $u$ istraživanju poduzetih analiza (primjerice, u području rodne socijalizacije, rodne ideologije ili pak utjecaja materijalnih strukturnih čimbenika na podjelu kućanskih poslova), one nisu mogle biti detaljno prikazane u članku časopisne dužine. Taj smo nedostatak pokušali umanjiti prikazom velikog broja narativa koji sadržavaju bogatstvo podataka o elementima izostalim iz izravne eksplikacije. Drugim riječima, oslonili smo se na tzv. "čitateljsku generalizaciju”, odnosno pretpostavljenu sposobnost "utemeljenog razumijevanja" prikazane empirijske građe u odnosu na relevantne sociološke koncepte (Misco, 2007).

Ukupno gledano, doprinos članka može se smatrati dvojakim. S jedne strane, omogućen je nov pogled na tematiku obavljanja kućanskih poslova, koji pridonosi boljem razumijevanju rodne dinamike u kućanstvima u Hrvatskoj. S druge strane, doprinos rada u teorijskom polju odnosi se integraciju Bourdieuova pristupa strategijama u rodnu analizu. Naime, ona je dosad posve izostala, ne samo u Bourdieuovu radu, nego i u kasnijim istraživačkim primjenama njegovih postavki. Konačno, poticajnim smatramo i to što se predloženi teorijsko-metodološki pristup može primijeniti u daljnjim istraživanjima povezanosti praksi muškaraca i žena s rodnim poredcima, odnosno konstrukcijama muškosti i ženskosti u pojedinom društvenom kontekstu.

\section{FINANCIJSKA POTPORA}

Ovaj je rad financirala Hrvatska zaklada za znanost projektom HRZZ-IP-2016-06-6010. 


\section{LITERATURA}

Babović M i Cvejić SP (2002). Strategije opstanka domaćinstava u Srbiji, Sociologija, 44 (2): 97-126. https://doi.org/10.2298/SOC0202097B

Bagić D, Dobrotić I, Lažnjak J, Rodik P i Vučković Juroš T (2017). Coping Strategies of Economically (Partially) Inactive Households: The Case of Croatia, Südosteuropa. Journal of Politics and Society, 65 (3): 542-564. https://doi.org/10.1515/soeu-2017-0034

Barada V, Čop B i Kučer M (2011). Žene u ruralnim područjima Dalmacije. Nevidljivo polje svijeta rada? (Izvještaj istraživanja). Split: Domine.

Bartolac A i Kamenov Ž (2013). Percipirana raspodjela obiteljskih obveza među partnerima i doživljaj pravednosti u vezi, Sociologija i prostor, 51 (1): 67-90. https://doi.org/10.5673/ sip.51.1.4

Bazeley P (2013). Qualitative Data Analysis: Practical Strategies. London: Sage.

Bjørnholt M i Farstad GR (2012). 'Am I rambling?' On the Advantages of Interviewing Couples Together, Qualitative Research, 14 (1): 1-17. https://doi.org/10.1177/1468794112459671

Bourdieu P (1972). Esquisse d'une théorie de la pratique. Précéde de Trois études d'ethnologie kabyle. Genève: Librairie Droz. https://doi.org/10.3917/droz.bourd.1972.01

Bourdieu P (1980). Le sens pratique. Paris: Minuit.

Bourdieu P i Wacquant LJD (1992). An Invitation to Reflexive Sociology. Chicago: The University of Chicago Press.

Connell RW (1987). Gender and Power: Society, the Person, and Sexual Politics. Cambridge: Polity.

Crompton R, Lewis S i Lyonette C (ur.). (2007). Women, Men, Work and Family in Europe. Houndmills: Palgrave Macmillan. https://doi.org/10.1057/9780230800830

Cvetičanin P i Lavrič M (2017). Typology of Household Strategies of Action in Four Countries of Southeastern Europe in a Period of Economic Crisis, Südosteuropa. Journal of Politics and Society, 65 (3): 459-494. https://doi.org/10.1515/soeu-2017-0030

Čulig B, Kufrin K i Landripet I (2007). EU +?-. Odnos građana Hrvatske prema pridruživanju Republike Hrvatske Europskoj uniji. Zagreb: FF press i B.a.b.e.

Dey I (1993). Qualitative Data Analysis: A User-Friendly Guide for Social Scientists. New York: Routledge.

Dobrotić I i Laklija M (2012). Obrasci društvenosti i percepcija izvora neformalne socijalne podrške u Hrvatskoj, Društvena istraživanja, 21 (1): 39-58. https://doi.org/10.5559/ di.21.1.03

Dworkin SL (2015). Men at Risk: Masculinity, Heterosexuality and HIV Prevention. New York: New York University Press.

Efendić A, Cvetičanin P i Kumalić I (2017). Thriving and Surviving Activities of Households During the Crisis Period. Empirical Evidence from Southeastern Europe, Südosteuropa, Journal of Politics and Society, 65 (3): 495-519. https://doi.org/10.1515/soeu-2017-0032

Emmel N (2013). Sampling and Choosing Cases in Qualitative Research: A Realist Approach. London: Sage. https://doi.org/10.4135/9781473913882

Flick U (2007). Designing Qualitative Research. London: Sage. https://dx.doi. org/10.4135/9781849208826

Gibbs GR (2007). Analyzing Qualitative Data. London: Sage. https://doi. org/10.4135/9781849208574

Glaser BG i Strauss AL (1967). The Discovery of Grounded Theory. Strategies for Qualitative Research. New Brunswick, NJ: Aldine Transaction. 
Government of the Netherlands (2020). Gender Equality, https://www.government.nl/topics/ gender-equality (29. srpnja 2020.)

Hochschild A (s Machung A) (2003 [1989]). The Second Shift. New York: Penguin.

Karajić N (2002). Siromaštvo i neslužbeno gospodarstvo u Hrvatskoj - kvalitativni aspekti, Financijska teorija i praksa, 26 (1): 273-299.

Kelle U (2007a). Computer-Assisted Qualitative Data Analysis. U: Seale C, Gobo G, Gubrium J i Silverman D (ur.). Qualitative Research Practice. London: Sage, 443-459. https://doi.org/10.4135/9781848608191.d36

Kelle U (2007b). "Emergence" vs. "Forcing" of Empirical Data? A Crucial Problem of "Grounded Theory" Reconsidered, Historical Social Research/Historische Sozialforschung, Supplement 19: 133-156.

Klasnić K (2017). Utjecaj rodne podjele obiteljskih obveza i kućanskih poslova na profesionalni život zaposlenih žena. Zagreb: Pravobranitelj/ica za ravnopravnost spolova Republike Hrvatske.

Krais B (1991). Preface to the English edition. U: Bourdieu P, Chamboredon J-C i Passeron J-C, The Craft of Sociology: Epistemological preliminaries. Berlin: de Gruyter, v-ix.

Kristensen GK i Ravn MN (2015). The Voices Heard and the Voices Silenced: Recruitment Processes in Qualitative Interview Studies, Qualitative Research, 15 (6): 722-737. https://doi.org/10.1177/1468794114567496

Kroska A (2007). Gender Ideology and Gender Role Ideology. U: The Blackwell Encyclopedia of Sociology, https://onlinelibrary.wiley.com/doi/ abs/10.1002/ 9781405165518.wbeosg019 (29. srpnja 2020.) https://doi. org/10.1002/9781405165518.wbeosg019

Krstić N, Derado A, Naterer A i Kumalić I (2017). Small Farmers in Four Southeast European Countries. A Qualitative Analysis of Life Strategies in Twenty-Five Agricultural Households, Südosteuropa. Journal of Politics and Society, 65 (3): 565-588. https://doi. org/10.1515/soeu-2017-0035

Leinert Novosel S (1999). Žena na pragu 21. stoljeća. Zagreb: Ženska grupa TOD.

Lyonette C i Crompton R (2015). Sharing the Load? Partners' Relative Earnings and the Division of Domestic Labour, Work, Employment and Society, 29 (1): 23-40. https://doi. org/10.1177/0950017014523661

Maxwell JA (2013). Qualitative Research Design: An Interactive Approach. London: Sage.

Maxwell JA i Chmiel M (2014). Notes Toward a Theory of Qualitative Data Analysis. U: Flick U (ur.). The SAGE Handbook of Qualitative Data Analysis. London: Sage, 21-34.

McKay J (1997). Managing Gender: Affirmative Action and Organizational Power in Australian, Canadian and New Zealand Sport. Albany, NY: State University of New York.

Miles MB i Huberman AM (1984). Qualitative Data Analysis: A Sourcebook of New Methods. Beverly Hills, CA: Sage.

Miles MB i Huberman AM (1994). Qualitative Data Analysis: An Expanded Sourcebook. London: Sage Publications.

Misco T (2007). The Frustrations of Reader Generalizability and Grounded Theory: Alternative Considerations for Transferability, Journal of Research Practice, 3 (1), http:// jrp.icaap.org/index.php/jrp/article/view/45/77 (22. studenog 2020.)

Morris L (1989). Household Strategies: The Individual, The Collectivity and The Labour Market - The Case of Married Couples, Work, Employment and Society, 3 (4): 447-464. https://doi.org/10.1177/0950017089003004003 
Nyman C, Reinikainen L i Eriksson K (2018). The Tension between Gender Equality and Doing Gender: Swedish Couples' Talk about the Division of Housework, Women's Studies International Forum, 68: 36-46. https://doi.org/10.1016/j.wsif.2018.01.010

Oakley A (1974a). The Sociology of Housework. London: Martin Robertson.

Oakley A (1974b). Housewife. London: Allen Lane.

Omotosho BJ (2013). Gender Balance. U: Idowu SO, Capaldi N, Zu L i Gupta AD (ur.). Encyclopedia of Corporate Social Responsibility. Berlin i Heidelberg: Springer, 43. https://doi.org/10.1007/978-3-642-28036-8_624

Pahl RE (1984). Divisions of Labour. Oxford: Basil Blackwell.

Pahl RE (1985). The Restructuring of Capital, the Local Political Economy and Household Work Strategies. In: Gregory D and Urry J (eds). Social Relations and Spatial Structures. London: Macmillan, 242-265. https://doi.org/10.1007/978-1-349-27935-7

Puljiz V, Bežovan G, Matković T, Šućur Z i Zrinščak S (2008). Socijalna politika Hrvatske. Zagreb: Pravni fakultet Sveučilišta u Zagrebu.

Reinharz S i Chase SE (2003). Interviewing Women. U: Holstein JA i Gubrium JF (ur.). Inside Interviewing: New Lenses, New Concerns. Thousand Oaks: Sage, 73-91.

Rubić T (2013). NezaposInost i neformalna ekonomija u Hrvatskoj: analiza diskursa, Studia ethnologica Croatica, 25: 61-92.

Rubić T (2017). Nezaposleni u gradu: antropologija rada i neformalne ekonomije. Zagreb: Hrvatsko etnološko društvo.

Scwalbe ML i Wolkomir M (2003). Interviewing Men. U: Holstein JA i Gubrium JF (ur.). Inside Interviewing: New Lenses, New Concerns. Thousand Oaks: Sage, 55-72.

Šikić-Mićanović L (2001). Some Conceptualisations and Meanings of Domestic Labour, Društvena istraživanja, 10 (4-5): 731-766. https://doi.org/10.1515/soeu-2017-0033

Šikić-Mićanović L (2012). Skriveni životi. Prilog antropologiji ruralnih žena. Zagreb: Institut društvenih znanosti Ivo Pilar.

Šikić-Mićanović L (2017). Making Ends Meet. How Roma Families Living in Poverty Cope, Südosteuropa, Journal of Politics and Society, 65 (3): 520-541. https://doi.org/10.1515/ soeu-2017-0033

Tomić-Koludrović I (2015). Pomak prema modernosti: žene u Hrvatskoj u razdoblju "zrele" tranzicije. Zagreb: Naklada Jesenski i Turk, Hrvatsko sociološko društvo.

Tomić-Koludrović I i Kunac S (2000). Rizici modernizacije. Žene u Hrvatskoj devedesetih. Split: Stope nade.

Tomić-Koludrović I, Petrić M, Puzek I i Zdravković Z (2018). Rodni stavovi i prakse u Hrvatskoj. Izvještaj o kvantitativnim rezultatima projekta GENMOD, Institut društvenih znanosti Ivo Pilar - Područni centar Split. https://www.pilar.hr/wp-content/ uploads/2020/01/GENMOD_Izvjestaj_kvantitativni_rezultatima_Final.pdf studenog 2020.)

Topolčić D (2001). Muškarci to ne rade: rodno segregirana podjela rada u obitelji, Društvena istraživanja, 10 (4-5): 767-789.

Topolčić D (2003). Sociologijski aspekti neplaćenog rada u obitelji: bračni partneri između obiteljskih i radnih uloga (doktorska disertacija), Sveučilište u Zagrebu, Filozofski fakultet.

Vučinić-Palašek G (1995). Stavovi prema ženama, rezultati istraživanja, Zagreb (neobjavljeni materijal).

Weiss RS (1994). Learning from Strangers. The Art and Method of Qualitative Interview Studies. New York: The Free Press. 


\title{
Relational Gender Strategies in the Division of Household Labour
}

\author{
Augustin DERADO (iD https://orcid.org/0000-0003-0114-6792 \\ Institute of Social Sciences Ivo Pilar, Croatia \\ augustin.derado@pilar.hr \\ Mirko PETRIĆ (iD https://orcid.org/0000-0002-0604-5352 \\ Institute of Social Sciences Ivo Pilar and Sveučilište u Zadru, Croatia \\ mirko.petric@pilar.hr
Inga TOMIĆ-KOLUDROVIĆ (D) https://orcid.org/0000-0003-1465-0365
Institute of Social Sciences Ivo Pilar, Croatia
inga.tomic-koludrovic@pilar.hr

\section{ABSTRACT}

The article presents the results of a qualitative inquiry into the gender division of household labour in Croatia, in the wider context of the total work practices of a household (i.e., total paid and unpaid work contributing to the realisation of its goals). The data were gathered through 92 semi-structured interviews ( 34 with men, 43 with women, and 15 with partners), carried out in all Croatian regions, with a high degree of variation in socio-demographic characteristics. Relational gender analysis was applied, the theoretical framework of which rested primarily on Bourdieu's praxeological approach to the concept of strategy, as well as on Pahl's conceptualisation of total work of the household and Hochschild's analysis of the gender dimension of strategies. Categorisation processes included three levels of coding (referential, open, and selective) while linking processes included the construction of analytical profiles and tables. The individual gender strategies identified relating to the performance of household labour are the strategies of unquestionability, resistance to change, cooperation, and proactive egalitarianism (for men), and the strategies of unquestionability, pressure, acceptance and proactive egalitarianism (for women). Bringing into relation the afore-mentioned male and female individual gender strategies and applying the criterion of gender balance resulted in the following typology of the household strategies related to the division of household labour: unquestioningly traditional, predominantly traditional, partly egalitarian, and proactively egalitarian. The component of justification concerning the division of household labour appears partially in both male and female individual strategies. The theoretical contribution of the analysis lies with the application of Bourdieu's praxeological approach to strategies in relational gender research.

Key words: division of household labour, relational gender analysis, qualitative research, Bourdieu, gender strategies 
